\title{
Analysing the Provisions Effectiveness at European level for Guaranteeing Equal Pay Amongst Genders
}

\section{Analisando a Eficácia das Disposições em Nível Europeu para Garantir a Igualdade de Remuneração Entre Sexos}

\author{
Charles Alves de Castro
}

Technological University Dublin, Ph.D. in Business, Irlanda

E-mail: charlesturcastro@yahoo.com.br

\begin{abstract}
This article aims to briefly understand and evaluate the main current European provisions for equal pay amongst genders. According to the European statistics compiled in 2012, the average differential in pay between the genders was $16 \%$ (in favour of men). In light of this statistic, this article critically analyses the provisions effectiveness at European level for guaranteeing equal pay. This research was carried out through a literature review. This is important to demonstrate, explain, and evaluate the current existent literature about this specific theme covered in this article. Furthermore, the literature review gives accuracy and validation to this research. In conclusion, there is a discuss ion on the challenges faced by European legislation to reduce unequal wages. The main finding relies on the evidence that women still earn less than men, even working at the same job. However, women had an efficient development over discrimination, offering them women effective legis lation, although this factor explains only a little part of the pay gap.
\end{abstract}

Keywords: Equal Pay. Human Resources. Employees. Europe.

\section{Resumo}

Este artigo tem como objetivo compreender e avaliar brevemente as principais disposições europeias para com a igualdade de re muneração entre os sexos. Segundo as estatísticas europeias compiladas em 2012, o diferencial médio de remuneração entre os sexos foi de $16 \%$ (a favor dos homens). De acordo com este dado, este artigo analisa criticamente a eficácia das disposições em nível europeu para garantir a igualdade de remuneração. Esta pesquisa foi realizada por meio de uma revisão de literatura. Isso é importante para demonstrar, explica r e avaliar a literatura existente sobre esse tema específico abordado neste artigo. Além disso, a revisão de literatura fornece precisão e validação para esta pesquisa. Em conclusão, há uma discussão sobre os desafios enfrentados pela legislação europeia para reduzir a desigualdade salarial. O resultado principal demonstra que as mulheres ainda ganham menos que os homens, mesmo trabalhando no mesmo emprego. No entanto, tiveram um desenvolvimento eficiente para superar a discriminação, oferecendo às mulheres uma legislação eficaz, embora esse fator explique apenas uma pequena parte da desigualdade salarial.

Palavras-chave: Igualdade Salarial. Recursos Humanos. Colaboradores. Europa.

\section{Introduction}

This essay aims to critically review and analyse the provisions effectiveness at European level for guaranteeing equal pay. The first point discussed relates to the gender pay gap in Europe, such as definition, impact, importance and implications; also, the positive and negative effects of the strategies that Europe Commission has been doing to reduce the gender pay gap was analyzed.

To evidence this research,surveys, articles, reports, journals and books to gain a broad understanding of this area were used. Furthermore, the study that examined the gender pay gap were also used to back up information gathered by the author, such as Eurostat - Development of econometric methods to evaluate the Gender pay gap using Structure of Earnings Survey data, European Union Commission - Tackling the gender pay gap in the European Union, Irish Congress of Trade Unions and the EC Year of Equal Opportunities for All 2007 - Equal Pay Overview Analysis and others.

\section{Development}

\subsection{Methodology}

This research was carried out thorugh a literature review. This is important to demonstrate, explain, and evaluate the current existent literature about the article theme. Furthermore, through this review, previous research in this area was compared and contrasted. Further study beyond the literature was necessary to fulfill the goals of this research. This was undertaken in the form of qualitative research. Qualitative research is a broad term that covers a wide range of techniques and philosophies. In simple terms, a qualitative research method can be defined as an approach that allows a researcher to examine people's experiences in detail by using specific research methods such as in-depth interviews, focus groups, observation, content analysis, life histories, or biographies (HENNINK et al. 2010). 


\subsection{The gender pay gap in Europe}

According to European Commission Website - Gender Pay Gap (2015) ' the gender pay gap is defined as the relative difference in the average gross hourly earnings of women and men within the economy as a whole" (European Commission Website - Gender Pay Gap, 2015). It still exists today due to wider gender inequalities through the economy and in society (European Commission Justice, 2014).

Women in the EU earn around $16 \%$ less per hour than men (European Commission - Eurostat, 2012). The gender pay gap varies across Europe, being below $10 \%$ in Slovenia, Malta, Poland, Italy, Luxembourg and Romania, but broader than 20\% in Hungary, Slovakia, Czech Republic, Germany, Austria and Estonia. Although the overall gender pay gap has narrowed in the last decade, in some countries, the national gender pay gap has been widening, such as Hungary and Portugal (European Commission, 2015).

The main effects on the gender pay gap over a lifetime are that women have earned less over their lifetimes; this results in lower pensions and a risk of poverty in old age. In 2012, 21.7\% of women aged 65 and over were at risk of poverty, compared to $16.3 \%$ of men (European Commission - Wages and Labour Costs, 2014). Furthermore, women are the majority of part-time workers in the EU, with $34.9 \%$ of women working part-time against only $8.6 \%$ of men 5 , thus, this has a negative impact on career progression, training opportunities, pension rights and unemployment benefits, all of which affect the gender pay gap (European Commission Gender Pay Gap, 2015).

However, the gender pay gap is not an indicator of the overall inequality between women and men since it only concerns employed people (European Commission - Gender Pay Gap, 2015). On the other hand, the gender pay gap is still a complex problem generated by several interrelated factors (European Commission - Justice, 2014).

The leading causes of the gender pay gap could be related to discrimination in the workplace, differentiation in jobs and sectors, on workplace practices and pay systems, undervaluing of women's work and skills, fewer women in senior and leadership positions, in gender roles and traditions and balancing work and matriarchal responsibilities (EUROPEAN COMMISSION - JUSTICE, 2014).

OECD states that the progress towards gender equality and women's empowerment is vital and extremely important for improving economic, social and political conditions in developed and developing countries (OECD "Men and Women in OECD countries", 2015). Therefore, the benefits of closing the gender pay gap are: creating a fairer and more equal society, supplying quality jobs, excellent for business, work and the economy and avoiding litigation and complaints (European Commission - Justice, 2014). European Union has developed many strategies to reduce the gender pay gap. The strategies aim to create more jobs, achieving a higher employment rate for women as part of the overall employment target of $75 \%$ for all 20-64 year-olds. This ensures that there will be 20 million fewer people in or at risk of poverty and social exclusion by 2020 (European Commission - Gender Pay Gap, 2014).

The strategies of the European Commission consists of:

a Commission of communication on the gender pay gap. This proposed a series of actions to tackle the gender pay gap. These included: the better application of existing legislation, fighting the gender pay gap in employment policies, promoting equal pay among employers through social partnership and supporting the exchange of good practices through the EU (European Commission - Gender Pay Gap, 2014).

b. European Commission's Strategy for equality between women and men. (2010-2015) The main objective is closing the gender pay gap through legislative and non-legislative measures. Furthermore, the strategy sets out actions in five areas: the economy and labour market; equal pay; equality in senior positions; tackling gender violence; and promoting equality beyond the EU (European Commission - Gender Pay Gap, 2014)

c. Directive on Equal Pay for Equal Value Work: "The principle of equal pay for equal work or equal value work has been enshrined in Treaties since 1957 and is incorporatedin the Directive 2006/54/EC (Recast Directive). One of the Commission's priorities for the coming years will be to monitor the correct application and enforcement of the equal pay provisions of the Directive 2006/54/EC and to support employees, the Member States and other stakeholders by guiding the proper enforcement and application of the existing rules." (European Union - Tackling the gender pay gap in the European Union pag. 14 2014) (European Commission Gender Pay Gap, 2014).

d. Equality Pays Off (2012 and 2013) - This project was to support employers in their efforts to tackle the gender pay gap. It aimed to raise companies' awareness of the business case for gender equality and equal pay, that is, better access to the women's labour force potential in a context of demographic changes and skills (European Commission - Gender Pay Gap, 2014).

e. European Equal Pay Day - The European Equal Pay Day is an annual event to raise awareness on the fact that a wage gap between women and men still exists and that women need to work longer than men to earn the same. The data vary s every year, depending on the average EU gender pay gap (European Commission - Gender Pay Gap, 2014).

In terms of legislation, the Article 141 of the EC treaty states that "Each member state shall ensure that the principle of equal pay for male and female workers for equal work or equal value work is applied" (EUROPEAN LEGISLATION, 2014).

The European Court of Justice has held that this provision is directly useful in national law (Case 43/75 Defrenne 1976 ECR 455). In addition, there is an EC directive which provides further guidance concerning the implementation of equal pay principle (75/117/EEC).

The Equal Pay Directive develops the equal pay principle, providing:

a any job classification system which is used for determining compensation must be based on the same criteria for both men and women and be so drawn up as to exclude 
any discrimination on the grounds of sex (Mel Cousin, 'Irish Congress of Trade Unions and the EC Year of Equal Opportunities for all, 2007').

b. There must be no provisions which are contrary to the equal pay principle in legislation, administrative rules, collective agreements, wage scales or individual employment contracts (Mel Cousin, 'Irish Congress of Trade Unions and the EC Year of Equal Opportunities for all, 2007').

c. Employees must be protected against victimisation for taking steps aimed at enforcing compliance with the equal pay principle (Mel Cousin, 'Irish Congress of Trade Unions and the EC Year of Equal Opportunities for all, 2007').

Although there is significant consensus about the gender pay equity principle in the EU countries, this essay, through many pieces of research, show that there is no easy way to achieve this goal. The equal pay principle is established in law, the differentiated wage scales of men and women were banished a long time ago, and today many collective agreements emphasize the principle of 'equal pay for equal work'. Therefore, a significant wage gap between women and men, and that the move towards a narrowing of wage disparities in working life has been progressing slowly (SOUMELI, 2002).

The general impression is that the strategies used by European Union are useful in specific points, on the other hand, the labour market gender equality, and especially the issue of pay equity, are not central issues in collective bargaining in the EU countries. Pay discrimination and pay differences are, to a certain degree regarded as a matter of legislation and politics, rather than a problem to be solved through collective agreements. This may be further explained by the fact that existing wage discrepancies between men and women are seen as a consequence of positional differences in working life, which is too large an issue to be solved through negotiations. Furthermore, the pay equity issue, at least in some countries, seems to be seen as less urgent than measures to increase women's employment participation rate, to make it easier to combine work and family, or to ease the re-entry of women (mothers) into working life (SOUMELI, 2002).

Furthermore, recourse to labour law - in the form of court cases and complaints to public authorities - is rarely used to combat gender pay discrimination. In most of the concerned countries in Europe, the number of such cases is somewhat limited. Therefore, as many will argue, the essential function of the legal framework is to prevent wage discrimination from taking place (SOUMELI, 2002).

In terms of equal pay and law aspects, this issue is much broader than merely ensuring that one person is paid the same rate as another doing similar work. Therefore, it is needed to do legal reform in order to assist in the implementation of equal pay in certain areas, such as: Developing the case law in relation to the new grounds under the Employment Equality Act such as age and disability. Issues such as how to identify discrimination based on these grounds and possible objective justifications raise important conceptual questions (COUSIN,
2007).

The strategies created by the European Union is competent in specific points, on the other hand, to supplement this issue many countries have adopted specific legislation on supporting the equality, as for example in Austria, sharing of childcare responsibilities through addressing the fathers' role; other countries have tried to increase and encourage female labour market participation after maternity leave. In the Nordic countries, in particular, the social partners have agreed on initiatives to tackle pay in sectors with a higher gender pay gap. In Sweden, for instance, a 'gender equality pool' provides low-paid employees with extra remuneration through employer contributions. The wage pools were collected according to a central agreement, but distribution took place through local bargaining to workplaces with a higher gender pay gap (EUROFOUND, 2010).

\section{Conclusion}

In conclusion, it is evident that women still earn less than men, even working at the same job. However, there have been an efficient development over the discrimination, offering women effective legislation, although this factor explains only a little part of the pay gap. Therefore, women's work is less important than the work that men do, while all other parameters are the same. Pay tables for jobs requiring similar skills, qualifications or experience tend to be lower when women predominantly perform them.

However, the only viable conclusion is that the road towards pay equity is proving a long one in the EU countries. There seems to be a consensus that the most critical challenges are related to positional inequalities in the labour market as well as the women integration into the labour market. Companies that promote equality in the workplace will create better jobs for all workers. Paying women and men concerning their competences and skills, furthermore valorizing their contribution on an equal basis can result in recruitment and retention of the most prepared staff. Employers should take advantage of the use of skills and talent of women in a more effective way to ensure that women benefit training and career development initiatives.

This is important to increase productivity and competitiveness. An increasing number of studies found a correlation between greater gender equality and profitability, especially in senior management jobs. Other bodies of research indicate a correspondence between gender balance in management teams and innovation capacity. Closing the pay gap between women and men can help to create a more cohesive and equal society. It helps to empower women and increase their financial independence. It might increase yields women during their working life and reduce levels of poverty, especially when they retire.

\section{References}

EUROFOUND. Addressing the gender pay gap: Government 
and social partner actions. 2010. Available in: <http://eurofound europa.eu/sites/default/files/ef_files/docs/eiro/tn0912018s/ tn0912018s.pdf. Access 30 mar. 2020

EUROPEAN COMMISSION - EUROSTAT. Development of econometric methods to evaluate the gender pay gap using structure of earning survey data. 2009. Available in: <http://ec.europa.eu/ eurostat/documents/3888793/5845617/KS-RA-09-011-EN.PDF/ a9b8bdd0-84cd-494f-9fd6-236727a5afb3?version=1.0 >. Access 15 mar. 2020

EUROPEAN COMMISSION - EUROSTAT. development of econometric methods to evaluate the gender pay gap using structure of earning survey data. 2012. Available in: <http://ec.europa. eu/eurostat/documents/3888793/5845617/KS-RA-09-011-EN. PDF/a9b8bdd0-84cd-494f-9fd6-236727a5afb3?version=1.0>Ç Access 15 mar. 2020.

EUROPEAN COMMISSION. Gender Pay Gap. 2015. Available in: <http://ec.europa.eu/justice/gender-equality/gender-pay-gap/ index_en.htm>. Access 20 mar. 2020.

EUROPEAN COMMISSION - JUSTICE. Report on Equality Between women and men. 2014. <http://ec.europa.eu/ justice/gender-equality/files/annual_reports/150304_annual_ report_2014_web_en.pdf > Access 29 mar. 2020.

EUROPEAN COMMISSION - GENDER PAY GAP. The Gender
Pay Gap in Europe from a legal Perspective 2010. Available in: $<$ http://ec.europa.eu/justice/gender-equality/files/gender_pay_ gap/genderpaygapfromlegalperspective-nov2010_en.pdf>. Access 20 mar. 2020

EUROPEAN COMMISSION. Wages and Labour Cost. 2014. Available in: <http://ec.europa.eu/eurostat/statistics-explained/ index.php/Wages_and_labour_costs>. Access 20 mar. 2020

EVA SOUMELI. 'Gender Pay Equity in Europe. 2002. Available in: <http://eurofound.europa.eu/observatories/eurwork/ comparative-information/gender-pay-equity-in-europe>. Access 28 mar. 2020.

HENNINK, M.; HUTTER, I.; BAILEY, A. Qualitative research methods. Thousand Oaks, CA, 2011.

HITCHCOCK, G.; HUGHES, D. Research and the Teacher: a qualitative introduction to school-based research, London: Routledge, 1989.

MEL COUSIN. Irish Congress of Trade Unions and the EC Year of Equal Opportunities for all 2007. Available in: <http://www. ictu.ie/download/pdf/overview_analysis_final.pdf $>$. Access 25 mar. 2020.

OECD. Men and Women in OECD countries. 2006. Available in: <http://www.oecd.org/std/37962502.pdf >. Access 23 mar. 2020. 